

Open Access

Asian Australas. J. Anim. Sci.

Vol. 27, No. 6 : 825-831 June 2014

http://dx.doi.org/10.5713/ajas.2013.13718

www.ajas.info

pISSN 1011-2367 elSSN 1976-5517

\title{
Determination of Nutrient Contents and In vitro Gas Production Values of Some Legume Forages Grown in the Harran Plain Saline Soils
}

\author{
M. Boga*, S. Yurtseven ${ }^{1}$, U. Kilic ${ }^{2}$, S. Aydemir ${ }^{3}$, and T. Polat ${ }^{4}$ \\ Bor Vocational School, Niğde University, TR 51240, Nigde, Turkey
}

\begin{abstract}
The aim of this study was to determine the nutritive value of some legume species in salt-affected soils of South-East Anatolian region using chemical composition and in vitro gas production kinetics. In this study, Lotus corniculatus, Trifolium alexandrinum, Medicago sativa were sown and tested in four different locations. A 3 by 4 factorial design with 3 legume species and 4 salt levels (non salty electrical conductivity $(\mathrm{EC})<4 \mathrm{dS} / \mathrm{m}$; low salt: $4 \mathrm{dS} / \mathrm{m}>\mathrm{EC}<8 \mathrm{dS} / \mathrm{m}$, medium saline: $8 \mathrm{dS} / \mathrm{m}>\mathrm{EC}<16 \mathrm{dS} / \mathrm{m}$ and high salt: $16 \mathrm{dS} / \mathrm{m}>\mathrm{EC}$ ) was used in the study. Results indicated that salinity and plants had no significant effect on ash and ether extract. Dry matter (DM), acid detergent fiber, digestible dry matter, dry matter intake (DMI) were affected by plant, salinity and plant $\times$ salinity interaction. On the other hand neutral detergent fiber, relative feed value (RFV), and DMI were affected by salinity and plant $\times$ salinity interaction. Mineral contents were affected by plant species, salinity and salinity xplants interactions. In vitro gas production, their kinetics and estimated parameters such as were not affected by salinity whereas the gas production up to $48 \mathrm{~h}$, organic matter digestibility, metabolizable energy $(\mathrm{ME})$, and net energy lactation $\left(\mathrm{NE}_{\mathrm{L}}\right)$ were affected by plant and plant $\times$ salt interaction. Generally RFVs of all species ranged from 120 to 210 and were quite satisfactory in salty conditions. Current results show that the feed value of Medicago sativa is higher compared to Lotus corniculatus and Trifolium alexandrinum. (Key Words: In vitro Gas Production, Glycophyte Forages, Legume sp., Relative Feed Value, Salt Stress)
\end{abstract}

\section{INTRODUCTION}

Salinity and sodicity are major challenges for South Anatolian Region of Turkey, especially the Sanliurfa Harran plain. Crop production has increased in the area by rising water tables with the start of the Atatürk Dam irrigation. As water tables rise they bring salts from deep in the soil profile to the surface. It is predicted that increasing salt

\footnotetext{
* Corresponding Author: M. Boga. Tel: +90-3883114527, Fax: +90-3883118437, E-mail: mboga@nigde.edu.tr

${ }^{1}$ Department of Animal Science, Faculty of Agriculture, Harran University, TR-63100 Şanlıurfa, Turkey.

${ }^{2}$ Department of Animal Science, Faculty of Agriculture, Ondokuz May1s University, TR 55139, Samsun, Turkey.

${ }^{3}$ Department of Soil Science, Faculty of Agriculture, Harran University, TR-63100, Şanlıurfa, Turkey.

${ }^{4}$ Department of Field Crops, Faculty of Agriculture, Harran University, TR-63100, Şanlıurfa, Turkey.

Submitted Nov. 14, 2013; Revised Jan. 8, 2014; Accepted Jan. 31, 2014
}

levels in soils will lead to marked reductions in yields of forage plants grown in the region (Taban et al., 1999). In Harran Plain dryland salinity has already reached 132,000 ha of irrigated agricultural land from total 225,000 ha of Harran area (Aydemir et al., 2005). Although Legumes as fodder crop are more sensitive to salinity than Poaceae, use of salt resistant plants such as some perennial and annual legumes (for example Medicago sativa, Lotus corniculatus, Trifolium alexandrinum) offer an opportunity to reduce the feed shortages associated with soil salinity and to improve the productivity of salt-affected land.

In vitro gas production has been developed as a predictive tool of nutrient content and in vitro DM digestibility has been widely used (Menke and Steingass, 1988; Getachew et al., 2004) to assess the nutritional quality of feeds due to its high correlation with in vivo digestibility. Although the mechanisms of salt injury and salt tolerance of whole plants have been studied extensively, the effects of salt stress on nutrient content, in vitro gas 
production, organic matter degradability, metabolic and net energy lactation levels of these legume plants hay have not been determined.

The objective of this study was to determine the feed values of different legume hays (Medicago sativa, Lotus corniculatus, Trifolium alexandrinum) grown in saltaffected soils of South-east Anatolian region as assessed by gas production parameters, intake, and digestibility and nutrient composition.

\section{MATERIALS AND METHODS}

This study was conducted over the period from autumn 2006 to autumn 2009 at University of Harran (Sanliurfa province) and University of Cukurova (Adana province) of the Republic of Turkey. Cultivation area was between Urfa mountains in north and Turkey-Syria border in south. All of the samples were grown at Harran plain and Akçakale from Sanliurfa province and the salt levels in these regions were identified in four different locations and then they were grouped according to their level of salt. Harran University in the northern region was not salty but Akçakale was very heterogeneous in terms zone salinity and salinity levels ranged between 10 and 21 electrical conductivity (EC) $\mathrm{dS} / \mathrm{m}$. The university district represented unsalted soils (2-6 $\mathrm{EC} \mathrm{dS} / \mathrm{m}$ ) but the salt level was detected as low, medium, high in Akçakale plain. The experiments began in autumn 2006 and lasted for three years. This study was aimed to test the nutrient content of different of glycophyte legume species growing in different salt-affected soils by in vitro gas production. So we chose three leguminous crops to study the effect of salinity on plant nutrient use and in vitro parameters. Trial was transformed into salinity plant species interactions $(3 \times 4)$. A 3 by 4 factorial design with 3 legume species and 4 salt levels as main effects was used. Soil salinity was expressed as EC. Three species of legumes were tested in two different locations having four saline levels (non salty EC $<4 \mathrm{dS} / \mathrm{m}$; low salt: $4 \mathrm{dS} / \mathrm{m}>\mathrm{EC}<8 \mathrm{dS} / \mathrm{m}$, medium saline: $8 \mathrm{dS} / \mathrm{m}>\mathrm{EC}<16 \mathrm{dS} / \mathrm{m}$ and high salt: 16 $\mathrm{dS} / \mathrm{m}>\mathrm{EC}$ ). Studies were conducted in natural areas and plants were sown in these lands. Soil salinity was measured twice a year. Ground water height or water table did not change significantly during the experiments. There was no problem associated with excessive irrigation and drainage. Therefore, no change occurred in the level of salinity (EC) in the experiments.

The study experimental design was randomized 3 blocks according to topographical characteristics to determine the effects on the legume species after three years by taking account some necessary nutrient aspects such as metabolic and net energy content via in vitro gas production technique. Three legume species were harvested in the beginning of blooming by cutting at ground level and then were field-dried. After that the samples were ground in a laboratory mill to pass through a $1 \mathrm{~mm}$ screen for chemical analyses and for incubation in in vitro gas production assays. Dry matter, crude protein, ash and ether extract of feeds were analyzed according to AOAC (1998) procedure. Crude protein was calculated as $\mathrm{N} \times 6.25$. Acid detergent fiber (ADF) and neutral detergent fiber (NDF) analysis were based on the method of Van Soest et al. (1991) using ANKOM fiber analyzer. All chemical analyses were carried out in triplicate for each replication of plants.

\section{$\mathrm{Ca}, \mathrm{Na}, \mathrm{Mg}$, and $\mathrm{K}$ analyses in plants}

Representative $500 \mathrm{~g}$ moist plant samples taken from each plot were dried at $70^{\circ} \mathrm{C}$ until constant weight. After drying, solutions of ground plants with a mixture of perchloric acid were subjected to the process of wet burning. Mineral substances from the plant solution after the burning process were determined by reading with ICP-OES (Chapman and Prat, 1982).

\section{Calculation of relative feed value, digestible dry matter, and dry matter intake}

Relative feed value (RFV) is a widely accepted forage quality index in the marketing of hays in the United States of America. The RFV combines the estimates for forage digestibility and intake into a single number and it is calculated from estimation of ADF and NDF (Ward, 2008). The RFV index was estimated the digestible dry matter (DDM) of the samples from ADF values, and was calculated the dry matter intake (DMI) potential (as a percent of body weight, BW) from NDF values. The index was then calculated as DDM multiplied by DMI as a \% of BW and divided by 1.29 (Jerenyama and Garcia, 2004).

$\mathrm{DDM}=88.9-(0.779 \times \% \mathrm{ADF})$

DMI $(\%$ of $\mathrm{BW})=120 /(\% \mathrm{NDF})$

$$
\mathrm{RFV}=(\mathrm{DDM} \times \mathrm{DMI}) / 1.29
$$

\section{In vitro gas production technique}

Three Holstein cows aged 5 years with ruminal cannulas (average live weight $650 \mathrm{~kg}$ ) were used to provide rumen fluid for the in vitro gas production technique. Rumen fluid was obtained from the fistulated cows fed twice daily (08.30 to 16.30$)$ with a diet containing corn silage $(60 \%)$ and concentrates $(40 \%)$ (Table 3$)$.

Approximately $200 \mathrm{mg}$ dry weight of samples was weighed in triplicate into $100 \mathrm{~mL}$ calibrated glass syringes following the procedures of Menke and Steingass (1988). The syringes were pre-warmed at $39^{\circ} \mathrm{C}$ before the injection of $30 \mathrm{~mL}$ rumen fluid-buffer mixture $(1: 2)$ into each syringe and incubated in a water bath at $39^{\circ} \mathrm{C}$. Gas volumes were 
Table 1. Chemical compositions of forage and concentrate fed to animals

\begin{tabular}{|c|c|c|c|c|c|c|c|}
\hline Feeds & $\mathrm{DM}(\mathrm{g} / \mathrm{kg})$ & $\mathrm{CP}$ & $\mathrm{EE}$ & $\mathrm{CF}$ & Ash & NDF & $\mathrm{ADF}$ \\
\hline Forage (Corn silage) & 318.3 & 105.7 & 35.1 & 236.1 & $\begin{array}{r}M--- \\
88.8\end{array}$ & 453.6 & 296.1 \\
\hline Concentrates & 907.9 & 281.4 & 44.3 & 96.2 & 60.7 & 266.9 & 93.4 \\
\hline
\end{tabular}

DM, dry matter; CP, crude protein; EE, ether extracts; NDF, neutral detergent fiber, ADF, acid detergent fiber.

recorded at $0,3,6,9,12,24,48,72$, and $96 \mathrm{~h}$ of incubation. Cumulative gas production data were fitted to the model of Ørskov and McDonald (1979) by NEWAY computer package program.

$$
\mathrm{y}=\mathrm{a}+\mathrm{b}\left(1-\mathrm{e}^{-\mathrm{ct}}\right)
$$

Where, a, the gas production from the immediately soluble fraction $(\mathrm{mL}) ; \mathrm{b}$, the gas production from the insoluble fraction $(\mathrm{mL})$; $\mathrm{c}$, the gas production rate constant for the insoluble fraction $(\mathrm{mL} / \mathrm{h}) ; \mathrm{a}+\mathrm{b}$, potential gas production $(\mathrm{mL}) ; \mathrm{t}$, incubation time $(\mathrm{h}) ; \mathrm{y}$, gas produced at time " $t$ ". Organic matter digestibility (OMD), metabolizable energy (ME) (Menke et al., 1979) and net energy lactation $\left(\mathrm{NE}_{\mathrm{L}}\right)$ (Menke and Steingass, 1988) contents of forages were estimated using equations given below:

$$
\begin{aligned}
& \operatorname{OMD}(\%)=14.88+0.889 \mathrm{GP}+0.45 \mathrm{CP}+0.651 \mathrm{~A} \\
& \mathrm{ME}(\mathrm{MJ} / \mathrm{kg} \mathrm{DM})=2.20+0.136 \mathrm{GP}+0.0574 \mathrm{CP} \\
& \mathrm{NE}_{\mathrm{L}}(\mathrm{MJ} / \mathrm{kg} \mathrm{DM})=0.101 \mathrm{GP}+0.051 \mathrm{CP}+0.112 \mathrm{EE}
\end{aligned}
$$

Where; GP, 24 h net gas production (mL/200 mg DM);
$\mathrm{CP}$, crude protein (\%); A, Ash content (\%); EE, Ether extracts $(\%)$.

\section{Statistical analysis}

Study was repeated 3 years and each year was taken as a block. But plant samples by combining three years were analyzed to compare nutrient contents, gas production parameters, energy, DDM and OMD values using General Linear Model (GLM) of Minitab (Version 16.0, 2006) package programs. All parameters from 3 Legume species with 4 salinity levels were analyzed using $3 \times 4$ factorial designs. Multiple comparisons among individual means were made with Minitab 16.0 in factorial designs.

\section{RESULTS}

\section{Nutrient contents of legume species grown in soils with four salt levels}

Chemical compositions of all forages are presented in Table 2. The dry matter content of each legume plant significantly changed among species and showed significant change with the salt levels, and the interaction of

\begin{tabular}{|c|c|c|c|c|c|c|c|c|c|c|}
\hline Plants & Salinity & $\mathrm{DM}$ & $\mathrm{NDF}$ & $\mathrm{ADF}$ & Ash (\%) & $\mathrm{CP}(\%)$ & $\mathrm{EE}(\%)$ & RFV & DDM & DMI \\
\hline \multirow[t]{4}{*}{ Lotus curniculatus } & Non salt & $92.5^{\mathrm{ab}}$ & $44.5^{\mathrm{c}}$ & $40.5^{\mathrm{e}}$ & $10.8^{\mathrm{a}}$ & $14.9^{\mathrm{a}}$ & $2.4^{\mathrm{ab}}$ & $120.1^{\mathrm{a}}$ & $57.3^{\mathrm{a}}$ & $2.7^{\mathrm{a}}$ \\
\hline & Low salt & $92.9^{\mathrm{abc}}$ & $44.2^{\mathrm{c}}$ & $37.2^{\text {cde }}$ & $11.4^{\mathrm{ab}}$ & $17.6^{\mathrm{ab}}$ & $2.9^{\mathrm{ab}}$ & $126.7^{\mathrm{a}}$ & $59.9^{\mathrm{abc}}$ & $2.7^{\mathrm{a}}$ \\
\hline & Medium salt & $93.2^{\text {cde }}$ & $39.3^{\mathrm{bc}}$ & $34.4^{\mathrm{bcd}}$ & $12.9^{\mathrm{bc}}$ & $18.2^{\mathrm{b}}$ & $3.2^{\mathrm{ab}}$ & $128.4^{\mathrm{a}}$ & $62.1^{\mathrm{bcd}}$ & $2.6^{\mathrm{a}}$ \\
\hline & High salt & $92.0^{\mathrm{a}}$ & $29.9^{\mathrm{a}}$ & $27.5^{\mathrm{a}}$ & $13.3^{\mathrm{c}}$ & $18.9^{\mathrm{b}}$ & $2.5^{\mathrm{ab}}$ & $210.2^{\mathrm{c}}$ & $67.5^{\mathrm{e}}$ & $4.1^{\mathrm{c}}$ \\
\hline \multirow{4}{*}{$\begin{array}{l}\text { Trifolium } \\
\text { alexandrinum }\end{array}$} & Non salt & $94.9^{f}$ & $34.8^{\mathrm{ab}}$ & $31.5 .5^{\mathrm{ab}}$ & $12.2^{\mathrm{abc}}$ & $19.9^{\mathrm{bc}}$ & $2.1^{\mathrm{ab}}$ & $167.2^{\mathrm{b}}$ & $65.8^{\mathrm{de}}$ & $3.4^{\mathrm{b}}$ \\
\hline & Low salt & $94.4^{\mathrm{def}}$ & $42.4^{\mathrm{bc}}$ & $32.7^{\mathrm{bc}}$ & $11.7^{\mathrm{abc}}$ & $17.6^{\mathrm{bc}}$ & $2.0^{\mathrm{a}}$ & $139.2^{\mathrm{ab}}$ & $63.5^{\text {bcde }}$ & $2.8^{\mathrm{ab}}$ \\
\hline & Medium salt & $94.8^{f}$ & $40.8^{\mathrm{bc}}$ & $37.6^{\mathrm{de}}$ & $11.3^{\mathrm{abc}}$ & $17.6^{\mathrm{bc}}$ & $3.2^{\mathrm{b}}$ & $132.9^{\mathrm{a}}$ & $59.6^{\mathrm{ab}}$ & $2.9^{\mathrm{ab}}$ \\
\hline & High salt & $94.2^{\mathrm{de}}$ & $43.6^{\mathrm{bc}}$ & $36.7^{\mathrm{cd}}$ & $13.1^{\mathrm{c}}$ & 20.3 & $2.9^{\mathrm{ab}}$ & $128.6^{\mathrm{a}}$ & $60.3^{\mathrm{abc}}$ & $2.8^{\mathrm{ab}}$ \\
\hline \multirow[t]{4}{*}{ Medicago sativa } & Non salt & $94.6^{\mathrm{def}}$ & $39.7^{\mathrm{bc}}$ & $32.6^{\mathrm{bc}}$ & $11.7^{\mathrm{abc}}$ & $22.4^{\mathrm{cd}}$ & $2.0^{\mathrm{ab}}$ & $153.2^{\mathrm{ab}}$ & $63.2^{\text {bcde }}$ & $3.1^{\mathrm{ab}}$ \\
\hline & Low salt & $93.3^{\mathrm{bcd}}$ & $39.9^{\mathrm{bc}}$ & $32.1^{\mathrm{ab}}$ & $10.9^{\mathrm{a}}$ & $22.8^{\mathrm{d}}$ & $2.6^{\mathrm{ab}}$ & $149.8^{\mathrm{ab}}$ & $63.9^{\text {cde }}$ & $3.0^{\mathrm{ab}}$ \\
\hline & Medium salt & $94.6^{\mathrm{ef}}$ & $36.2^{\mathrm{ab}}$ & $30.9^{\mathrm{ab}}$ & $12.2^{\mathrm{abc}}$ & $23.3^{\mathrm{d}}$ & $2.2^{\mathrm{ab}}$ & $170.3^{\mathrm{b}}$ & $64.6^{\mathrm{de}}$ & $3.4^{\mathrm{b}}$ \\
\hline & High salt & $92.4^{\mathrm{a}}$ & $36.2^{\mathrm{ab}}$ & $30.6^{\mathrm{ab}}$ & $11.6^{\mathrm{abc}}$ & $22.6^{\mathrm{cd}}$ & $2.7^{\mathrm{ab}}$ & $169.1^{\mathrm{b}}$ & $65.1^{\mathrm{de}}$ & $3.3^{\mathrm{b}}$ \\
\hline SEM & & 0.1 & 0.6 & 0.5 & 0.2 & 0.3 & 0.1 & 3.3 & 0.5 & 0.05 \\
\hline Plants & & $* *$ & NS & $*$ & NS & $* *$ & NS & NS & $*$ & NS \\
\hline Salinity & & $* *$ & $* *$ & $* *$ & NS & NS & NS & $* *$ & $* *$ & $* *$ \\
\hline Plants $\times$ salinity & & $*$ & $* *$ & $* *$ & NS & NS & NS & $* *$ & $* *$ & $* *$ \\
\hline
\end{tabular}
species by salinity. Trifolium alexandrinum had highest DM content.

Table 2. Chemical compositions, RFVs, DDMs and DMIs of samples used in the study

RFV, relative feed value; DDM, digestible dry matter (\% of body weight); DMI, dry matter intake (\% of body weight); DM, dry matter; NDF, neutral detergent fiber; ADF, acid detergent fiber; CP, crude protein; EE, ether extracts; SEM, standard error of means; NS, no significant differences.

$* \mathrm{p}<0.05 ; * * \mathrm{p}<0.01$.

${ }^{\mathrm{a}-\mathrm{e}}$ Significance between individual means was identified using the Duncan's multiple comparative tests. 
Results indicated that salinity and plants had no significant effect on ash and ether extract. Dry matter (DM), ADF, DDM, DMI were affected by plant, salinity and plant $\times$ salinity interaction. On the other hand NDF, RFV, and DMI were affected by salinity and plant $\times$ salinity interaction. Generally RFVs of all species ranged from 120 to 210 and were quite satisfactory in salty conditions. Mineral contents also were affected by plant species, salinity and salinity $\times$ plants interactions.

In vitro gas production kinetics and estimated parameters such as were not affected by salinity whereas the gas production up to $48 \mathrm{~h}, \mathrm{OMD}, \mathrm{ME}$, and $\mathrm{NE}_{\mathrm{L}}$ was affected by plant and plant $\mathrm{x}$ salt interaction.

\section{DISCUSSION}

The nutrient components of all plants were relatively similar for four salinity levels except for Lotus corniculatus (Table 2). This may be attributed to its characteristic structure. Lotus corniculatus is more resistant compared to Medicago sativa. According to Bakir (1985); Lotus corniculatus has been reported to be resistant to soil salinity of 12 to $16 \mathrm{dS} / \mathrm{m}$. For this reason, Lotus corniculatus is recommended in hot, arid regions such as the Harran plain. All components, especially $\mathrm{CP}$ is enough to cover ruminant nutrient requirements. According to El Shaer (2010), most of salt tolerant fodders attain reasonable CP, although they have high ash content. Furthermore, such plants grown in saline soils are usually fairly poor in energy and high in CP (Le Houérou et al., 1982). These studies showed that salt stress tended to enhance CP content of Lotus corniculatus compared other legume species. The increase in CP content of this forage is likely attributed to its structural properties. Leaf loss of Lotus corniculatus was the greatest during drying (Aydemir et al., 2011). But it was not main subject of this study and fresh and dry matter yield were not provided. Leaf loss caused an increase in NDF. NDF is inversely proportional to $\mathrm{HP}$ in plants. Lower $\mathrm{CP}$ in Lotus corniculatus can be attributed to the high NDF content and leaf loss (Table 2). On the other hand, Fougere et al. (1991) suggested that salt stress induced a large increase in the amino acid and carbohydrate contents in some legume plants. Salt tolerant plant species contain high crude protein and salt and low metabolic energy (Norman et al., 2002). But, it is known that salt stress generally decreases productivity in all plants. The CP content averaged $19 \%$ in legume plants used in the present study which was enough to cover the protein requirements of small ruminants.

The ADF content of Lotus corniculatus decreased with increasing soil salinity levels. The specific effects of ADF on feed intake are already known. The DMI of Trifolium alexandrinum showed low values due to the increased salt levels in soil. Soil salinity has been reported to negatively influence feed intake and digestibility because of thenreduction in nitrogen uptake (Mashhady et al., 1982). Absence of significant changes in nutrient content of alfalfa indicated that these alfalfa varieties growing on saline soils can produce high to moderate consumable biomass for livestock feeding at four salt levels $(4 \mathrm{dS} / \mathrm{m}<\mathrm{EC}<16 \mathrm{dS} / \mathrm{m})$ of soil series. The specific mechanisms of tolerance to salinity that are used by alfalfa are unknown (Smith, 1998). Alfalfa plants utilize salt exclusion as a mechanism to cope with salinity issues and they do exclude $\mathrm{Na}^{+}$but do not exclude $\mathrm{Cl}^{-}$(Brown and Hayward, 1956; Lauchb, 1984).

Table 3. Mineral components of legume plants cultivated from different salt-affected fields

\begin{tabular}{lccccc}
\hline & $\begin{array}{c}\text { Mineral components } \\
\text { ( }\end{array}$ & \multicolumn{3}{c}{ Salinity level } \\
\cline { 3 - 6 } & $\mathrm{K}$ & Non-salty & Low salty & Medium salty & High salty \\
\hline Lotus curniculatus & $\mathrm{Na}$ & 18.6 & 19.3 & 13.8 & 11.5 \\
& $\mathrm{Ca}$ & 144.6 & 138.4 & 172.7 & 150.5 \\
& $\mathrm{Mg}$ & 94.9 & 103.5 & 98.1 & 100.3 \\
Trifolium alexandrinum & $\mathrm{K}$ & 16.3 & 32.5 & 30.8 & 29.1 \\
& $\mathrm{Na}$ & 26.0 & 36.6 & 28.5 & 32.8 \\
& $\mathrm{Ca}$ & 145.3 & 70.9 & 155.2 & 137.3 \\
Medicago sativa & $\mathrm{Mg}$ & 105.9 & 134.5 & 81.3 & 102.2 \\
& $\mathrm{~K}$ & 13.3 & 26.1 & 20.3 & 24.3 \\
SEM & $\mathrm{Na}$ & 140.0 & 12.7 & 19.5 & 17.8 \\
Legume species & $\mathrm{Ca}$ & 115.0 & 93.6 & 168.1 & 171.4 \\
Salinity level & $\mathrm{Mg}$ & 15.7 & 23.3 & 93.1 & 93.6 \\
Legume species $\times$ salinity level & & 0.41 & 1.34 & 20.9 & 21.1 \\
\hline
\end{tabular}

SEM, standart error mean. ${ }^{*} \mathrm{p}<0.05 ; * * \mathrm{p}<0.01$. 
Alfalfa is more salt tolerant because it is able to regulate the uptake and translocation of $\mathrm{Na}^{+}$and $\mathrm{Cl}^{-}$to prevent excessive accumulation of these ions in leaves (Munns, 2005).

Salinity resulted in a significant accumulation of some minerals (except $\mathrm{Ca}$ ) especially in Medicago sativa. Data on mineral content revealed that $\mathrm{K}$ retention was significantly affected by the levels of soil salinity in Lotus corniculatus. Salinity caused a cubic accumulation of $\mathrm{Na}$ mineral especially in Lotus corniculatus and Trifolium alexandrinum. Jia et al. (2008) suggested that high salt levels impose both ionic and osmotic stresses on plants, resulting in an excessive accumulation of sodium $(\mathrm{Na})$ in plant tissues. Because the mentioned minerals were higher in the Akçakale region than the Harran region (Ikizce soil series), some of the mineral contents of plants such as $\mathrm{Mg}$, $\mathrm{Na}, \mathrm{K}$, and $\mathrm{Ca}$ were higher in this area. Suyama et al. (2007) reported more $\mathrm{Na}$ accumulation for 'Salado' alfalfa grown under irrigation with drainage water causing soil salinity of 5.2 to $6.4 \mathrm{dS} / \mathrm{m}$. It is well known that at a whole plant level, salinity stress induces an increase in $\mathrm{Na}$, as well as a decrease K and Ca concentrations (Lutts, 1996). Salinity also causes the rate of photosynthesis to decrease and causes the nutrient uptake and $\mathrm{Ca}^{++}$transport to decrease (Taban and Katkat, 2000). Although concentrations of $\mathrm{Mg}$, $\mathrm{Na}$ and $\mathrm{K}$ were higher than the level of non-salty soils, the concentrations are still within the maximum tolerance levels for sheep and beef cattle specified by NRC (1984, 1985). As stated by Masters et al. (2001), sheep can tolerate a sodium chloride intake in feed of about 100 to $150 \mathrm{~g} / \mathrm{d}$ provided that they have access to a non saline drinking water. Although the high $\mathrm{Na}$ and $\mathrm{K}$ content may limit feed intake, $\mathrm{K}$ did not lead to a reduction in feed consumption due to reduced $\mathrm{K}$ in Lotus corniculatus. However, we do not know whether these forages growing under salty conditions are consumed less than in current conditions because this trial was not an in vivo study. Therefore more in vivo studies are required to determine the effect on the feed intake of ruminants. There were no significant differences among groups with salinity levels in terms of the in vitro gas production, the immediately soluble fraction $a$, the gas production from the insoluble fraction $b$ and the rate of gas production constant from the insoluble fraction $\mathrm{c}$ $(\mathrm{p}<0.05)$ (Table 4). This can be attributed to the similar ash, $\mathrm{CP}$ and ether extract values in salinity conditions for each plant. In this study, the nutrient content of all species was at a similar level for microbial fermentation. It is well documented that the nutrient contents of feeds effect their potential production of gas quantity and level of gas produced tends to decrease or increase with changing chemical content of feeds (Doane et al., 1997; Abdulrazak et al., 2000). Poor energy of plants in saline soils is frequently seen (Abdulrazak et al., 2000). All varieties had approximately ME of 7.2 MJ/kg DM. In general, ME values below $7 \mathrm{MJ} / \mathrm{kg} \mathrm{DM}$ are considered to be unacceptable for beef cattle and goats (NRC, 1981;1984). Varieties with ME values between 7 and $9 \mathrm{MJ} / \mathrm{kg} \mathrm{DM}$ are suitable for low production or maintenance level of beef cattle but not acceptable for dairy cattle and rapidly growing calves.

The Hay Marketing Task Force of the American Forage and Grassland Council (AFGC) endorses the use of RFV as a measure of forage quality (Linn and Martin, 2008). According to the Quality Grading Standard assigned by the Hay Market Task Force of AFGC, the RFV values were founded as "Premium" 2 or "Prime" for all legume species in current study and they were quite satisfactory levels in

Table 4. In vitro gas production $(\mathrm{mL})$ parameters and $\mathrm{ME}, \mathrm{NE}_{\mathrm{L}}$ and $\mathrm{OMD}$ values of Legume species

\begin{tabular}{|c|c|c|c|c|c|c|c|c|c|c|c|c|c|c|c|}
\hline Plants & Salinity & 3 & 6 & 9 & 12 & 24 & 48 & 72 & 96 & $\mathrm{a}$ & $\mathrm{b}$ & $\mathrm{c}$ & OMD & $\mathrm{ME}$ & $\mathrm{NE}_{\mathrm{L}}$ \\
\hline \multirow{4}{*}{$\begin{array}{l}\text { Lotus } \\
\text { curniculatus }\end{array}$} & Non salt & $2.6^{\mathrm{b}}$ & $5.9^{\mathrm{b}}$ & $10.3^{b}$ & $14.7^{\mathrm{b}}$ & $26.9^{\mathrm{cd}}$ & $35.5^{\mathrm{ab}}$ & $40.1^{\mathrm{bc}}$ & $41.5^{\mathrm{bc}}$ & $-3.7^{\mathrm{abc}}$ & 46.0 & 0.04 & $46.2^{f}$ & $6.7^{\mathrm{e}}$ & $3.7^{\mathrm{ef}}$ \\
\hline & Low salt & $2.0^{\mathrm{b}}$ & $5.4^{\mathrm{bc}}$ & $10.5^{\mathrm{b}}$ & $15.3^{\mathrm{b}}$ & $27.7^{\mathrm{cd}}$ & $38.5^{\mathrm{ab}}$ & $41.6^{\mathrm{abc}}$ & $43.1^{\mathrm{abc}}$ & $-5.2^{\mathrm{c}}$ & 49.1 & 0.05 & $48.2^{\mathrm{ef}}$ & $7.0^{\text {cde }}$ & $4.0^{\mathrm{def}}$ \\
\hline & Medium salt & $5.5^{\mathrm{a}}$ & $8.9^{\mathrm{a}}$ & $13.9^{\mathrm{a}}$ & $18.8^{\mathrm{a}}$ & $31.2^{\mathrm{ab}}$ & $40.3^{\mathrm{a}}$ & $44.3^{\mathrm{ab}}$ & $45.9^{\mathrm{ab}}$ & $-1.5^{\mathrm{ab}}$ & 47.1 & 0.05 & $51.6^{\mathrm{bc}}$ & $7.5^{\mathrm{ab}}$ & $4.4^{\mathrm{abc}}$ \\
\hline & High salt & $2.5^{\mathrm{b}}$ & $5.8^{\mathrm{bc}}$ & $10.0^{\mathrm{b}}$ & $14.2^{\mathrm{b}}$ & $25.4^{\mathrm{d}}$ & $30.7^{\mathrm{b}}$ & $38.1^{\mathrm{bc}}$ & $39.9^{\mathrm{bc}}$ & $-2.2^{\mathrm{abc}}$ & 42.6 & 0.04 & $46.9^{\mathrm{ef}}$ & $6.8^{\mathrm{de}}$ & $3.8^{\mathrm{ef}}$ \\
\hline \multirow{4}{*}{$\begin{array}{l}\text { Trifolium } \\
\text { alexandrinum }\end{array}$} & Non salt & $1.9+$ & $5.2^{\mathrm{c}}$ & $10.0^{\mathrm{b}}$ & $14.7^{\mathrm{b}}$ & $26.9^{\mathrm{cd}}$ & $37.0^{\mathrm{ab}}$ & $40.0^{\mathrm{bc}}$ & $41.5^{\mathrm{bc}}$ & $-5.0^{\mathrm{c}}$ & 47.2 & 0.05 & $48.3^{\mathrm{def}}$ & $7.0^{\text {cde }}$ & $3.9^{\mathrm{def}}$ \\
\hline & Low salt & $6.0+$ & $8.7^{\mathrm{a}}$ & $13.7^{\mathrm{a}}$ & $18.5^{\mathrm{a}}$ & $30.5^{\mathrm{abc}}$ & $39.4^{\mathrm{ab}}$ & $43.7^{\mathrm{abc}}$ & $45.3^{\mathrm{abc}}$ & $-0.8^{\mathrm{a}}$ & 46.6 & 0.04 & $51.7^{\mathrm{abcd}}$ & $7.6^{\mathrm{abc}}$ & $4.3^{\mathrm{bcd}}$ \\
\hline & Medium salt & $2.4^{\mathrm{ab}}$ & $5.7^{\mathrm{bc}}$ & $9.8^{\mathrm{b}}$ & $13.8^{\mathrm{b}}$ & $27.7^{\mathrm{cd}}$ & $29.8^{\mathrm{b}}$ & $37.1^{\mathrm{c}}$ & $38.8^{\mathrm{bc}}$ & $-2.1^{\mathrm{abc}}$ & 41.5 & 0.04 & $45.5^{\mathrm{f}}$ & $6.6^{\mathrm{e}}$ & $3.7^{\mathrm{ef}}$ \\
\hline & High salt & $2.1^{\mathrm{b}}$ & $5.5^{\mathrm{bc}}$ & $10.8^{b}$ & $15.5^{\mathrm{b}}$ & $28.2^{\text {bcd }}$ & $38.8^{\mathrm{ab}}$ & $42.1^{\mathrm{abc}}$ & $43.6^{\mathrm{abc}}$ & $-5.3^{\mathrm{c}}$ & 49.5 & 0.05 & $49.5^{\text {cdef }}$ & $7.2^{\mathrm{bcd}}$ & $4.2^{\text {cde }}$ \\
\hline \multirow{8}{*}{$\begin{array}{l}\text { Medicago } \\
\text { sativa }\end{array}$} & Non salt & $5.8^{\mathrm{a}}$ & $8.9^{\mathrm{a}}$ & $13.9^{\mathrm{a}}$ & $18.7^{\mathrm{a}}$ & $31.0^{\mathrm{ab}}$ & $40.2^{\mathrm{a}}$ & $44.1^{\mathrm{ab}}$ & $45.8^{\mathrm{ab}}$ & $-1.2^{\mathrm{a}}$ & 47.4 & 0.04 & $53.3^{\mathrm{ab}}$ & $7.7^{\mathrm{a}}$ & $4.5^{\mathrm{ab}}$ \\
\hline & Low salt & $2.5^{\mathrm{b}}$ & $5.8^{\mathrm{bc}}$ & $10.1^{\mathrm{b}}$ & $14.4^{\mathrm{b}}$ & $26.3^{\mathrm{d}}$ & $34.6^{\mathrm{b}}$ & $39.1^{\mathrm{c}}$ & $40.6^{c}$ & $-3.6^{\mathrm{bc}}$ & 44.9 & 0.04 & $49.3^{\text {cdef }}$ & $7.1^{\text {cde }}$ & $4.1^{\mathrm{de}}$ \\
\hline & Medium salt & $1.9^{\mathrm{b}}$ & $5.7^{\mathrm{bc}}$ & $10.0^{\mathrm{b}}$ & $14.8^{\mathrm{b}}$ & $26.7^{\mathrm{d}}$ & $37.1^{\mathrm{ab}}$ & $40.1^{\mathrm{c}}$ & $41.6^{\mathrm{bc}}$ & $-5.0^{\mathrm{c}}$ & 47.4 & 0.05 & $49.9^{\text {cde }}$ & $7.2^{\text {bcd }}$ & $4.1^{\mathrm{de}}$ \\
\hline & High salt & $5.9^{\mathrm{a}}$ & $9.1^{\mathrm{a}}$ & $14.3^{\mathrm{a}}$ & $19.1^{\mathrm{a}}$ & $31.8^{\mathrm{a}}$ & $41.0^{\mathrm{a}}$ & $45.2^{\mathrm{a}}$ & $46.8^{\mathrm{a}}$ & $-1.3^{\mathrm{a}}$ & 48.5 & 0.04 & $54.1^{\mathrm{a}}$ & $7.8^{\mathrm{a}}$ & $4.7^{\mathrm{a}}$ \\
\hline & SEM & 0.2 & 0.04 & 0.08 & 0.1 & 0.2 & 0.4 & 0.3 & 0.4 & 0.1 & 0.5 & 0.001 & 0.2 & 0.03 & 0.02 \\
\hline & Plants & $*$ & $* *$ & $* *$ & $* *$ & $* *$ & $*$ & NS & NS & NS & NS & NS & $* *$ & $* *$ & $* *$ \\
\hline & Salinity & NS & NS & NS & NS & NS & NS & NS & NS & NS & NS & NS & NS & NS & NS \\
\hline & Plants $\times$ salinity & $* *$ & $* *$ & $* *$ & $* *$ & $* *$ & $* *$ & $* *$ & $* *$ & $*$ & $*$ & $*$ & $* *$ & $* *$ & $* *$ \\
\hline
\end{tabular}

ME, metabolizable energy; $\mathrm{NE}_{\mathrm{L}}$, net energy lactation; $\mathrm{OMD}$, organic matter digestibility; a, the gas production from the immediately soluble fraction $(\mathrm{mL})$; b, the gas production from the insoluble fraction $(\mathrm{mL})$; c, the gas production rate constant for the insoluble fraction $(\mathrm{mL} / \mathrm{h})$; SEM, standard error of means; NS, no significant differences. $* \mathrm{p}<0.05 ; * * \mathrm{p}<0.01$.

${ }^{\mathrm{a}-\mathrm{f}}$ Significances between individual means were identified. 
salty soil conditions (all plants ranged from 120.1 to 210.2; Table 2).

In conclusion, this study showed that these legume species can be used as salt tolerant forages for ruminant diets in areas with soil salinity. These glycophyte species (especially Medicago sativa) can meet forage quality standards and they yield highly edible biomass on saline lands where non-salt tolerant species cannot grow. In these areas, a shortage of feed resources is a common problem and is considered as a major constraint to increasing livestock productivity. The DMI and RFV did not show a negative trend under current salinity conditions except Trifolium alexandrinum (Table 2). Where animal production systems are based on forage from soils with higher salt concentrations more attention should be given to Trifolium alexandrinum if salt free water is in limited supply. On the other hand, salinity does not have a significant impact on the nutritional value of these plants under all salinity conditions. Provided sufficient water consumption, accumulation of mineral elements in Medicago sativa and Lotus corniculatus plants does not limit the DM consumption.

\section{ACKNOWLEDGMENTS}

We thank project owners (TOVAG-106O145) for allowing us use of plant materials and we are grateful to Agricultural Faculty members of Harran University for their help extended in identification. We are also most grateful to the Harran University of Şanlıurfa, Cukurova University of Adana, and Ondokuz Mayıs University of Samsun-Turkey for permission to work and analyses in the feed laboratory.

\section{REFERENCES}

Abdulrazak, S. A., T. Fujihara, J. K. Ondilek, and E. R. Orskov. 2000. Nutritive evaluation of some Acacia tree leaves from Kenya. Anim. Feed Sci. Technol. 85:89-98.

AOAC. 1998. Officinal Methods of Analysis. 16th Edition, AOAC International, Gaithersburg, MD, USA.

Aydemir, S., M. A. Cullu, T. Polat, O. Sonmez, M. Dikilitas, and H. Akil. 2008. Harran Plain soils facing salinity problems and their possible amelioration status. In: Proceedings of the Irrigation and Salinity Conference, 12-13 June 2008, Sanliurfa, Turkey, pp. 45-62.

Aydemir, S., T. Polat, M. A. Çullu, C. Kaya, O. Sönmez, B Hacıkamiloğlu, M. Dikilitaş, S. Yurtseven, E. Doğan, A Sürücü, and S. Karakas. 2011 Adaptation of glycohyte and halophyte fodder crops to the Saline Soils of Harran Plain and their amendatory effects on physico-chemical characateristics of soil. Tubitak Project Report. Project No: 106 O 145.

Bakir, O. 1985. Pasture Improvement Strategies. Ankara University, Ankara. p. 272.

Brown, J. W. and H. E. Hayward, 1956. Salt tolerance of alfalfa varieties. Agron. J. 48:18-20.
Chapman, H. D. and P. F. Pratt. 1982. Methods of analysis for soils, plants and water. Methods of Soil Analysis Part 1: Physical and Mineralogical Methods 2nd Edition. Agronomy Series No: 9. Am. Soc. Agronomy and Soil Sci. Soc. Am. Inc. Publisher, Madison, Wisconsin USA.

Doane, P. H., P. Schofield, and A. N. Pell. 1997. Neutral detergent fiber disappearance and gas and volatile fatty acid production during the in vitro fermentation of six forages. J. Anim. Sci. 75:3342-3352

El Shaer, H. M. 2010. Halophytes and salt-tolerant plants as potential forage for ruminants in the Near East region. Small Rumin. Res. 91:3-12.

Fougere, F., D. Le Rudulier, and G. John. 1991. Streeter effects of salt stress on amino acid, organic acid, and carbohydrate composition of roots, bacteroids, and cytosol of alfalfa (Medicago sativa L.). Plant Physiol. 96:1228-1236.

Getachew, G., P. H. Robinson, E. J. De Peters, and S. J. Taylor. 2004. Relationships between chemical composition, dry matter degradation and in vitro gas production of several ruminant feeds. Anim. Feed Sci. Technol. 111:57-71.

Jeranyama, P. and A. D. Garcia. 2004. Understanding relative feed value (RFV) and relative forage quality (RFQ). Cooperative Extension Service, South Dakota State University, Brookings, SD, USA. http://pubstorage.sdstate.edu/AgBio_Publications/ articles/exex8149.pdf Accesed September 27, 2011.

Jia, Y. X., L. Sun, F. He, L. Q. Wan, Q. H. Yuan, and X. L. Li. 2008. Analysis of effects of salt stress on absorption and accumulation of mineral elements in elymus spp. using atomic absorption spectrophotometer. Guang Pu Xue Yu Guang Pu Fen Xi. 28:2984-2988.

Lauchb, A. 1984. Salt exclusion: An adaptation of legume for crops and pastures under saline condition. In: Salinity Tolerance in Plants. Strategies for Crop Improvement (Eds. R. C. Stoples and G. H. Toenniessen). John Willey and Sons, Tolonto, Canada. pp. 171-187.

Linn, J. G. and N. P. Martin. 1999. Forage quality tests and interpretations. University of Minnesota Extension Service, Minneapolis (1989) (MN AG-FO-02637).

Lutts, S., J. M. Kinet, and J. Bouharmont. 1996. Effects of salt stress on growth, mineral nutrition and proline accumulation in relation to osmotic adjustment in rice (Oryza sativa) cultivars differing in salinity resistance. Plant Growth Regul. 19:207218

Mashhady, A. S., H. I. Sayed, and M. S. Heakal. 1982. Effect of soil salinity and water stresses on growth and content of nitrogen, chloride and phosphate of wheat and triticale. Plant Soil 68:207-216

Menke, K. H., L. Raab, A. Salewski, H. Steingass, D. Fritz, and W. Schneider. 1979. The estimation of the digestibility and metabolizable energy content of ruminant feedingstuffs from the gas production when they are incubated with rumen liquor in vitro. J. Agric. Sci. Camb. 93:217-222.

Menke, K. H. and H. Steingass. 1988. Estimation of the energetic feed value obtained from chemical analysis and in vitro gas production using rumen fluid. Anim. Res. Dev. 28:7-55.

Munns, R. 1993. Physiological processes limiting plant growth in saline soils: Some dogmas and hypotheses. Plant Cell Environ.16:15-24.

Norman, H. C., D. G. Masters, R. A. Dynes, and D. A. Henry. 2002. 
Live weight change and wool growth in young sheep grazing a mixed saltbush and balansa clover pasture. Anim. Prod. Aust. 24: 334 .

NRC. 1981. Nutrient Requiremets of Domestic Animals N0.15. Nutrient Requirements of Goats. National Academy Press, Washington, DC, USA.

NRC. 1984. Nutrient Requiremets of Small Ruminants. National Academy Press, Washington, DC, USA.

NRC. 1985. Nutrient Requiremets of Beef Cattle Ruminants. National Academy Press, Washington, DC, USA.

Ørskov, E. and I. Mcdonald. 1979. The estimation of protein degradability in the rumen from incubation measurements weighted according to rate of passage. J. Agric. Sci. Camb. 92: 499-503.

Smith, S. E. 1998. Evaluating salt tolerance: some experiences with nondormant alfalfa. In: Proceedings of the 36th North American Alfalfa Improvement Conference. August 2-6, 1998; Bozeman, MT, USA. p. 24-25.
SPSS, 2006. Windows Evaluation Version (Base 15.0). Chicago, IL, USA.

Suyama, H., S. E. Benes, P. H. Robinson, G. Getachew, S. R. Grattan, and C. M. Grieve. 2007. Biomass yield and nutritional quality of forage species under long-term irrigation with saline-sodic drainage water: Field evaluation. Anim. Feed Sci. Technol. 135:329-345.

Taban, S. and V. Katkat. 2000. Effect of salt stress on growth and mineral elements concentrations in shoot and root of maize plant. J. Agric. Sci. 6:119-122.

Van Soest, P. J., J. B. Robertson, and B. A. Lewis. 1991. Methods for dietary fiber, neutral detergent fiber, and nonstarch polysaccharides in relation to animal nutrition. J. Dairy Sci. 74:3583-3597.

Ward, R. 2008. Relative feed value (RFV) vs. relative forage quality (RFQ). http://www.foragelab.com/Media/RFV_vs_ RFQ-CVAS\%20Perspective.pdf Accesed January 20, 2014. 